\title{
Teacher Use Of Interactive Read Alouds Using Nonfiction In Early Childhood Classrooms
}

Gayle M. Bortnem, Northern State University, USA

\begin{abstract}
Children enter kindergarten in the United States with large differences in their background knowledge, vocabulary, and early literacy experiences. There is a strong relationship between language development during the early years and reading ability in the primary grade and teachers must understand the importance of developing vocabulary and its relationship to literacy. It is essential that teachers provide time and effort to quality language experiences. One researched based strategy to accomplish this is the use of interactive read-alouds. Teachers have traditionally used fictional literature in the classroom, but there is growing research that nonfiction or informational literature are also needed to provide children with quality vocabulary building experiences in the early school years. This research study examined the results of a survey that was given to childcare providers and preschool through $2^{\text {nd }}$ grade teachers about the amount of time they read aloud to children and the amount of time they spend reading fiction compared to nonfiction text. Results showed that teachers in classrooms (pre-through $2^{\text {nd }}$ grade) reported reading to children almost every day, though the time devoted to this activity was a small percentage of the total time spent in class. Also, nonfiction literature was a small percentage of the literature that was being read to children. The findings in this paper have implications for practice in the field. Because vocabulary development is a key ingredient in the learning-to-read process and is a predictor of success in future reading skills, teachers in the early grades should be aware of the benefits of using interactive read alouds and the genre of nonfiction literature in vocabulary development.
\end{abstract}

Keywords: Vocabulary, emergent literacy, nonfiction, read alouds

\section{INTRODUCTION}

$\mathrm{n}$ their joint position statement, the IRA (International Reading Association) and the NAEYC (National Association for the Education of Young Children) emphasized the importance of providing young children with foundational knowledge in language acquisition, the reading and writing processes, and early literacy development (Newman, Bredekamp, \& Copple, 2000). This document states that the most important period for literacy development is from birth through age eight.

Former Assistant Secretary for the United States Department of Education, Susan Neuman, (2003), stated that children with multiple risk factors are likely to have had limited exposure to books, language, storybook reading, and other literacy-related activity known to provide a critical foundation for reading achievement. Children most at risk of developing reading problems are those who begin formal school with low language skills, less phonemic awareness and letter knowledge, and less familiarity with literacy tasks (Burns, Griffin, \& Snow, 1999). Many young children lack vital experiences in background knowledge that develop vocabulary and other important concepts for learning (Zill \& Collins, 2000).

A study by Hart and Risley (1995) found that by age four, children from high-socioeconomic-status (SES) families had been exposed to thousands more words than children from low-SES families. Children learn new 
vocabulary words at a rapid rate in their preschool years. One estimate is that they acquire about five new words each day between the ages of one and one half to six years (Carey, 1978). This could add up to about 10,000 words by the age of six. Children from disadvantaged backgrounds come to kindergarten with half as many words as the typical advantaged child (Stanovich, 1986).

There is no question in the education field, the pressure is on for young children to have the necessary skills to be ready to read fluently early in their school years. Children who fail to read in the $1^{\text {st }}$ grade have a one in eight chance of ever catching up to grade level without extraordinary and costly interventions (Juel, 1986, 2003). Children who start school behind will likely stay behind. Interventions that impact skills such as vocabulary and knowledge of narrative structures need to occur early in the preschool period if they are to have later effects during the decoding stages of learning to read (Neuman \& Dickinson, 2002). Consequently, early childhood teachers must provide quality literacy developing experiences to make this happen.

This study contributes to the literature and research in the field supporting the use of interactive read-alouds specifically using nonfiction literature in early childhood classrooms pre- through $2^{\text {nd }}$ grade. This type of intervention could help to equalize children's early experiences and decrease the gap or differences in vocabulary development of children at-risk. They would have the opportunity to develop a stronger foundation of language and vocabulary needed to succeed at learning to read. This information may help teachers that work with emergent and beginning readers to increase their awareness of the benefits of using nonfiction literature and interactive readalouds in the early school years. It also gives insight into the amount of time teachers are dedicating to read alouds to young children and specifically the genre of nonfiction.

\section{IMPORTANCE OF READ ALOUDS}

There is no lack of research for early childhood and early elementary classrooms in emphasizing the benefits of reading aloud to children. Interactive book read-alouds are an interactive student-text-teacher discourse (Smolkin, \& Donovan, 2001) and involves one person reading narrative or expository literature to another individual or group (Wiesendanger, 2001) and encouraging questions and discussion during and after the reading. Reading to children that involves (a) drawing attention to information in the illustrations, (b) using prediction and questioning, and (c) sharing related experiences (Klesius \& Griffith, 1996). Read-alouds immerse children in learning words and word knowledge that build vocabulary and a foundation for learning to read. It develops children's listening comprehension (Dickinson \& Smith, 1994) and is associated with increased achievement (Sulzby \& Teale, 2003).

Assertions regarding the efficacy of reading to preschoolers are found in many scholarly sources, including the report of the Commission on Reading of the National Academy of Education (1985), and numerous books and articles by educational researchers (Adams, 1990; Teale, 1984, 1986). The Commission on Reading found that "the single most important activity for building the knowledge required for eventual success in reading is reading aloud to children" (Anderson, Heibert, Scott, \& Wilkinson, 1985, p. 23). The listening comprehension and expressive use of language involved in read-alouds are recognized as key objectives in the Early Reading First program funded under the No Child Left Behind Act (U.S. Department of Education, 2002).

However, research also shows that numerous preschools and other group settings for young children often provide relatively impoverished language and literacy environments (Snow, Burns, \& Griffin, 1998). Teachers who work with young children must understand language and literacy development as it is essential that they provide quality experiences so that children can become successful readers (Burns et al., 1999).

There is a strong relationship between language development during the early years and reading ability in the primary grades (Schickedanz, 1999). A quantitative meta-analysis study to test effects of book reading on children's language and literacy development in preschool and elementary school (Bus et al. 1995) It was found that reading experiences were related to language growth and to outcome measures such as emergent literacy and reading achievement (Bus \& van Ijzendorryn, 1999). The young child develops emergent literacy skills that provide the foundation for early or beginning reading and ultimately the achievement of conventional, skilled reading (Justice \& Kaderavek, 2004). 
Children who have many oral language experiences and real-life or concrete experiences in quality preschool or home environments are able to build a foundation of understanding about language and vocabulary that supports learning to read (Hart \& Risley, 1995). Many factors can result in a lack of essential pre-reading and writing skills including low-income, racial minority groups and those with a native language that is not English (Snow, et al., 1998). All of these factors have been identified as at-risk for lacking skills in readiness for the rigors of kindergarten and beyond (Snow et al., 1998). Hart and Risley $(1995,1999)$ determined that family economics was a significant factor in children's language development. According to their study, children from low-income families heard less language and said fewer words.

There is also strong evidence that vocabulary skill is predictive of later reading achievement (Scarborough, 1998) while children with poor vocabulary skills are at increased risk for having trouble with early reading achievement (National Reading Panel, 2000). Whitehurst and Fischel (2000) studied the relationship between oral language and reading among beginning readers. Several hundred children from low-income families were followed when they entered Head Start at 4-years of age through the end of their fifth grade year as 10-year olds. Measures of reading and oral language abilities were collected at the end of each school year. Results showed that individual differences among children were set at the age of four and remained stable after that time. Reading success is directly and strongly dependent on skills that children bring from their experiences from the preschool and kindergarten period.

Families, child caregivers, and early childhood educators all have an impact on children's language and emerging literacy skills. The critical window of opportunity to offer support in helping children acquire rich language and emerging literacy skills is during these early years (Moats, 2000). Vygotsky's (1978) socialinteractionist perspective emphasized the role of social interactions with adults in the child's learning process. Adult-child interactions that support oral language acquisition facilitate early reading and writing development (Snow, 1983).

Children's concepts about literacy are formed from the earliest years by observing and interacting with readers and writers as well as through their own attempts to read and write (Sulzby \& Teale, 1991). Literacy develops as children make sense of the world around them and learn to explore how to use print to express meaning (Foster, Hough, \& Matthews, 1991). The early childhood years are important in the development of the "outside-in" skills. Through development of language from listening and interacting with adults, children build a foundation for their learning to read later. Studies on the interactions between adults and children during storybook readings and adult's mediation between the book and the child's learning show important effects on child's vocabulary development, enjoyment of reading, comprehension, phonemic awareness and expressive language (Sulzby \& Teale, 1996).

There has been much documentation on storybook reading and how it helps children become acquainted with language (Cazden, 1983; Chomsky, 1972; Sulzby \& Teale, 1987; Wells, 1986, 1987). Interactive dialogue, teacher and students discussing content during read-alouds, is a way to support vocabulary development (Durkin, 1972; Teal, 1986). According to Dickinson and Smith (1994), read-alouds can support children's developing ability to reason for themselves and with others if these events actively involve the children in discussions about the book being read. As children experience print through read-aloud events from adult models that use expression and enjoyment of the text, they are motivated to interact within a social context to share information about books (Reutzel, 2001).

Durkin (1970) in Teaching Them to Read stated that one way to promote children's interest in vocabulary was to read to them. Children can hear the words in context when they listen to a reading. The same book read multiple times seems to promote interest in particular words. Vygotsky (1978) stated that a child must hear words in context to understand them and eventually to read them. Reading to a young child is one way to stimulate language as the adult models the use of the words and provides scaffolds to help a child understand the written word.

Feitelson, Kita, and Goldstein (1986) conducted a study in which first graders took part in read-alouds for twenty minutes each day for six months. The children outscored the control group in decoding new words, 
developing listening comprehension, and using language more actively. The quality of experiences with children's book readings has important effects. A correlational study of teacher-child interaction during a book reading with four-year old low-income children found measurable effects on children's language learning a year later (Dickinson, 2001; Dickinson \& Smith, 1994). Comprehension skills are developed as the vocabulary becomes familiar and syntactic structures in books that have been read to the child (Morrow \& Smith, 1990).

Huck (1979) reported that interactive read-alouds should include an introduction to the selection, a discussion about the author and illustrator, discussion on new or unusual words, a follow up time, and children's interactions with and during the reading. Children's appreciation for literature seems to be developmental and sequential; the listening capacity of the child should be considered. Elley (1980) demonstrated that oral story reading was a significant source of vocabulary gain. In a study of 8-year old children, the researcher used pre and post testing to show that vocabulary acquisition was influenced by read-alouds. A test was developed from the words that were read. Then the data were analyzed for six word-related variables that were hypothesized to effect vocabulary gain. The learning was effective for students who scored low on the pretest as well as those whose scores that were high. She also found that if vocabulary terms were words that appeared several times in a story and in a meaningful context, there were gains in vocabulary development and an increase in interaction in book reading behavior occurred (Elley, 1989).

Studies involving preschool through elementary school-age children showed that story reading was a significant source of vocabulary gain (Brabham, Boyd, Edgington, 2000; Elley,1980, 1989; Ninio, 1980; Senechal, 1997; Sulzby \& Teale, 1996). There is extensive research demonstrating that read-alouds should be an essential component of building knowledge required for eventual success in reading (Anderson, Heibert, Scott, \& Wilkinson, 1985, Dickinson, 2001, Dickinson \& Smith, 1994 Morrow \& Smith, 1990).

Brabham, Boyd, and Edgington (2000) conducted a study with second through fourth graders in two schools. Students showed significant vocabulary gains when the teacher read aloud from a book with words they did not know previously. Though limited, the study had thorough scripting and testing which supported findings that children can learn vocabulary from read-alouds.

Penno, Wilkinson, and Moore (2001) conducted a study with 47 children who were 5- to 8-year olds to explore the effect of listening to stories on young children's vocabulary development. They found that the children's vocabulary did increase while listening to a story and even made greater gains when the teacher provided an explanation in the target vocabulary terms in the context of the story. However, this study also supported the research that listening to stories did not overcome the Matthew Effect,this is the phenomenon that suggests that skilled decoders get better at reading while poor decoders tend to fall further behind (Neuman, Copple, Bredkamp, 2000). Children with higher vocabularies still outperformed children with lower vocabularies. Evidence is growing to support the theory that children who struggle with reading early will continue to remain poor readers throughout their schooling (Adams, 1990; Juel, 1988; Stanovich, 1986). Reading nonfiction texts is a specific strategy that can enhance preschool children's understanding and acquisition of a rich vocabulary.

\section{USE OF NONFICTION OR INFORMATIONAL LITERATURE IN EARLY CHILDHOOD}

Most of the books utilized in previous studies on reading to preschool children have been fiction or narrative in nature. Studies show that there is limited use of nonfiction in the early childhood years and children listen to mostly fiction, narrative type stories (Caswell \& Duke, 1998; Duke, 2000; Moss, 1995; Pappas, 1991, 1993, 1997; Senacore, 1991). Duke (2000) determined that the presence of informational text in classrooms served to promote literacy early in a child's education. Information text is written with the primary purpose of conveying factual information such as books about nature like snakes or trees and things in the social world such as books about building bridges or holiday customs (Duke, 2003). Books having particular text features to give factual information using graphic elements, diagrams, photographs, language forms such as "birds eat insects" versus "that bird is eating an insect" (Duke, 2003). 
Pellegrini, et al.(1990) found that information books that explain, define, and provide examples tended to elicit more joint participation and teaching opportunities in a shared book reading with mothers than did fiction type stories. Informational texts share about the real world and offer specific vocabulary about people, places, events, and objects (Purcell-Gates \& Duke, 2001). Text used in nonfiction is different from the text in fiction stories. Rich language and emergent literacy skills are recommended when using read-alouds for utmost growth in vocabulary attainment (Snow et al., 1998). Nonfiction texts make it possible to build background knowledge and vocabulary in ways that narrative texts often do not. This genre makes it possible to link the real world and children's interests with learning to read (Caswell \& Duke, 1998).

Previous studies have maintained that elementary children benefit from using nonfiction, but there was a lack of research involving the use of this type of literature in the early childhood years. High-quality nonfiction books that have real pictures and vocabulary that support them are likely to expose children to richer language. Use of informational texts to help kindergarten and elementary children obtain knowledge about the world and to develop vocabulary has been explored (Duke, 2000; Pappas, 1991, 1993; Pellegrini, Perlmutter, Galda, and Brody,1990) but the use of fiction or narrative literature is still predominate in research with young children.

Traditionally, early childhood teachers focus on the use of narrative text that tells a story. Pappas (1991) found that a group of kindergarteners was capable of retelling both a child's narrative trade book and a child's nonnarrative one. Informational text is appropriate to read aloud to the emergent reader and can offer numerous benefits to the young child, as well as building vocabulary for learning to read. Maduram, (2000) studied her own child from age three to six and examined informational read-alouds and the child's responses to them. Her study showed that exposure to informational text was appropriate for young children and even stimulated more questions and vocabulary acquisition than narrative texts (Pellegrini et al., 1990).

Studies show that the majority of early childhood classrooms use fiction storybooks or narrative type texts for read-alouds or story time (Duke, 2003). There is an assumption that children will understand and make sense of a story that is fiction before they will be able to comprehend text that is a nonfiction text. There are many theories why narrative texts dominate the early year's classrooms. One predominate factor has been a traditional lack of quality and interesting books (e.g. Freeman \& Person, 1992) in this genre for young children. Another factor is the thought that use of narrative text is easier for the young emergent reader to understand, though there is no research to support this assumption.

McMath, King, and Smith (1998) state that reading quality informational books provides valuable resources for young children. This type of literature provides a venue for answering questions about the world around them, encouraging critical thinking, encouraging research or finding an answer that can stimulate more questions. In addition, they found that informational books could increase and extend concept development and provide practice for the content area reading that is needed later in the intermediate grades.

Use of informational or nonfiction text is developmentally appropriate in early childhood classrooms. Pappas (1993) found that kindergarteners could read informational books with interest and skill. Additional studies such as Duke and Kays (1998) show that informational texts are not too difficult for young children to understand and enjoy. They recommend including nonfiction in early childhood settings (Duke \& Kays, 1998).

Research has shown that students tend to select books that the teacher reads to them (Anderson, 1985). Teachers who use nonfiction read-alouds cultivate interest in children to discover this genre. Informational texts can play an important role in motivating children to read (Caswell \& Duke, 1998). Research has shown a link between children's interest and non-narrative, informational texts especially for struggling readers and writers. Research finds that children that read information that interests them increases their motivation to read (Caswell \& Duke, 1998).

Although there is little research at this time concerning specific genres and their influence on emergent readers and older children, some research suggests that children can acquire knowledge about types of text. PurcellGates (1988) asked kindergarten-aged children to pretend to read a wordless picture book that was suggestive of a 
fiction, narrative, fairy tale genre after they had been read aloud to at least five times per week for two years. She found the children produced readings using many of the features of the language of this genre. Duke and Kays (1998) studied kindergarten-aged children's knowledge of informational text after being exposed to readings for three months. The children showed greater knowledge of several features characteristic of this genre.

When young children hear narrative type stories, they learn the organization and format of this type of genre. When listening to informational text that has a different format, the child must develop other organizational techniques (Schickedanz, 1999). Pellegrini, Perlmutter, Galda, and Brody (1990) found in their study with Head Start mothers and their children that using nonfiction texts tended to elicit more joint participation and teaching opportunities.

Most of the research dealing with the use of informational text deals with children who are in second grade and up though there is emerging research that supports using nonnarrative and informational texts to help young children learn (Papa, 1991; 1993). First-grade children were documented as they interacted with expository texts. Duke (2000) found that young readers could interact successfully with informational texts and enjoyed reading this type of text. Kamil and Lane (1997) stated that an important reason to use informational text in early literacy development was learning to evaluate the truth-value in text and to use information books to solve problems.

In a descriptive, observational study of twenty first-grade classrooms, Duke (2000) compared the informational text experiences and exposure in ten school districts in the greater Boston area. The researcher found that this type of genre was rare, and in some low socioeconomic areas, nonexistent. The nature of books that are used in read-alouds is important because high-quality books are likely to expose children to richer language. Preschool children can understand and converse about non-story genres (Pappas \& Maduram, 1994). Research on the effects of book reading using quality nonfiction, informational text in preschool settings is limited as compared with studies of older students.

\section{TEACHERS ACTUAL USE OF READ ALOUDS}

Though the research is extensive on using read alouds as a strategy for building the emergent literacy skills of young children, research shows that a small percentage of the time in the classroom is spent using it. Dickinson and Tabors (2002) used interviews of preschool teachers to find how the typical day was organized and to understand the educational goals of the teachers. They found there was a wide variation in the amount of time teachers set aside for book reading. Their study followed 74 children from the preschool years through middle school. They based their study on the theory that rich language experiences during preschool would play an important role in children learning to read and comprehend in their middle school years. Twenty-five percent of the teachers reported planning more than 50 minutes of book reading a week when the children in the study were four years old. Approximately $17 \%$ reported planning for reading 15 minutes or less per week. Their findings led them to believe that preschool teachers lacked "well-articulated systems of belief that link understanding of the nature of language and literacy development with notions of effective classroom practices" (p.14).

This study also measured data from a Home-School Study of Language and Literacy Development (HSLLD), a longitudinal study of the development of language and literacy skills of children from low-income homes. Book reading practices both at home and at school were observed and recorded (Dickinson et al. 2001).

The level of language and literacy skills that the children had acquired by the end of their kindergarten year provided a strong basis for the acquisition of literacy and vocabulary skills in the later elementary years. Children's early learning set the stage for later literacy acquisition in school. (p.194)

After collecting data from separate studies throughout New England over a span of a decade, it was found that "book reading is not a vital daily ingredient in many classrooms" (Dickinson, 2002). Book reading in preschool was relegated to being used as a transitional activity, only on certain days of the week, or left out if children needed large motor activity. In addition, many classrooms relegated books to an area for free choice time and was only used if children showed interest. 
The primary goal of the read-aloud is the construction of meaning from the interactive process between adult and child (Vygotsky, 1978). Children who hear stories in small groups score significantly better in comprehension than those who were read to individually or in large groups (Morrow, 1987, 1988; Morrow \& Smith, 1990) and had more comments and questions. A number of studies have shown that oral language skills increase when children are involved in shared reading (Whitehurst, \& Epstein, 1994; Whitehurst \& Lonigan, 1998; Whitehurst et al., 1988). The use of dialogic reading, which focuses on how the adult reads books to children, has shown strong growth in children's language, and maintenance of this growth over time (Whitehurst et al., 1998).

Reading aloud should be an activity that teachers make a priority. A key element in the effect of storybook reading at home and school is how the adult mediates the reading in response to the children's reaction and initiations (Sulzby \& Teale, 1996). To advance children's oral language and literacy skills, the adult and the child use the read-aloud for conversation (Ninio, 1983; Teale, 1983).

Klesius and Griffith implemented a study using interactive storybook reading experiences with 10 kindergarten children. The participants were placed in two groups of five each and were identified as children whose language and literacy development fell below that of other students their age. The purpose of the study was to determine whether the interactive storybook routine could be implemented effectively and to identify the skills and knowledge teachers needed to support children during these reading events (Klesius \& Griffith, 1996). Their research verified the findings of Cochran-Smith (1986) and Strickland \& Morrow (1989) that young children learn how to use knowledge of the world along with textual information to understand stories. Discussions that encourage student inquiries and support their elaborations help their higher-level comprehension (Klesius et al.,1996).

Adult behaviors that support children's learning during story interactions are to clarify information, demonstrate, to develop story structure, to draw attention to illustrations, to extend student responses, to extend vocabulary, inform, meta-narrate the text and/or pictures, praise, to point out text features, and scaffold strategies of a reader. (p. 559)

Other points that the researchers emphasized as benefits of interactive storybook reading were that "children discover that books are a source of enchantment and wonder and trusted adults are seen as role models who engage in and enjoy reading experiences and the social aspect of interactive story book reading" (Klesius, p. 559). "An interactive read aloud cannot occur without sufficient time to read the book and to have the conversations that happen along the way" (Smolkin, 2003).

Researchers have shown that interactive book reading can enhance language development. With the heavy emphasis on teaching and testing to standards, how much time do teachers in the field actually read aloud and give it the emphasis that is needed for children's learning? Also, do teachers use strategies such as the use of nonfiction to build vocabulary? Are they aware of the benefits of using the genre of nonfiction? Early childhood teachers should be informed by current research and offer the young children in their programs opportunities to develop vocabulary through read alouds using fiction and nonfiction.

\section{POPULATION AND SAMPLE}

Participants in the read-aloud survey were from 23 childcare centers, 143 family childcare homes, seven group family childcare, three Head Start programs, and eight preschools from a list obtained from a state early childhood resource and referral program in the northeast portion of a Midwestern state. The Survey of Reading Aloud Habits was distributed to 161 preschool teachers and childcare providers in a newsletter sent out by a state office of an Early Childhood Enrichment program. In addition, 25 kindergarten, 21 first grade, and 20 second grade teachers participating in grade level workshops were given the survey. Those that chose to complete the survey were participants in the research. Total number of participants was 101 teachers. Out of 227, a total of 101 surveys were returned at a rate of $44 \%$. 


\section{INSTRUMENTATION AND DATA COLLECTION}

The survey designed by the researcher was sent out in a bi-monthly newsletter from a state office of an early childhood enrichment program in the community to preschool teachers and childcare providers. It was also handed out at three consecutive teacher training workshops; each for grade level teachers. The survey did not require names so it protected the anonymity of the participants.

The survey instrument was modeled after surveys by Jacobs, Morrison, and Swinhard (2000) and Lillebo (2003). The model was chosen because of its ease of completion and the belief that teachers can more easily remember how many days they have read aloud in a week and they can recall an approximate number of minutes read over that length of time. Teachers were asked about the amount of time they read aloud to children and the amount of time they spend reading fiction and nonfiction text.

Survey instruments used only multiple-choice items and did not include open-ended response items. The results of the convenience sample available for the study cannot be generalizable beyond the specific population from which the sample was drawn. The purpose of the data analysis of the survey questionnaire was to identify trends in time set aside in the early childhood classroom for read-alouds and nonfiction literature.

\section{DEMOGRAPHIC DATA OF THE SURVEY RESPONDENTS}

The survey asked 101 respondents to report their position (Table 1), educational background (Table 2), and years of experience (Table 3) in the early childhood field. Results of the survey revealed that 35 (34\%) were teachers in childcare or preschool. Kindergarten teachers made up $25(25 \%), 1^{\text {st }}$ grade teachers were $21(21 \%)$, and $20(20 \%)$ were $2^{\text {nd }}$ grade teachers.

\section{Table 1}

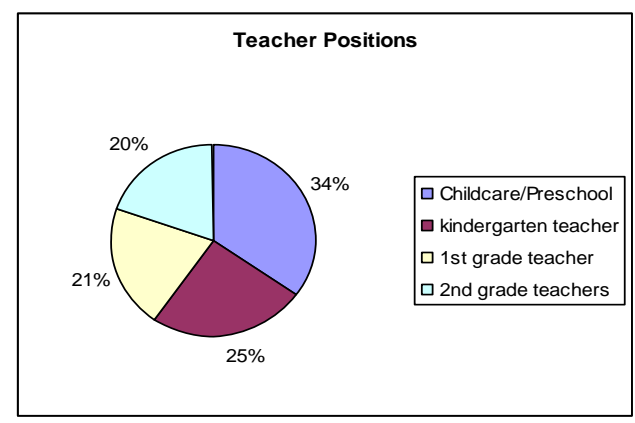

Table 2

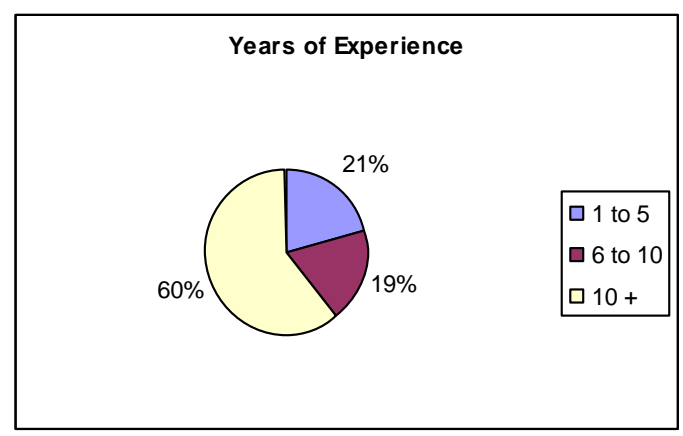

The survey also asked respondents the years of experience in the early childhood field. These results indicated that $59(60 \%)$ of the respondents had over ten years of experience in teaching. 18 respondents (19\%) had between six and ten years of experience. 20 respondents $(21 \%)$ had less than five years of experience.

The final demographic question on the survey asked respondents to provide their highest level of education. Though $28.6 \%$ of the respondents only had a high school education, $68.6 \%$ reported some education past high school. Some respondents did not answer all the questions so percentages do not equal $100 \%$. 
Table 3

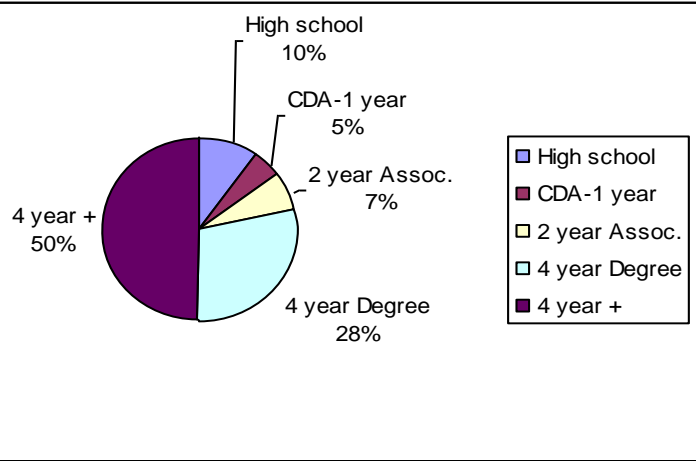

\section{RESEARCH FINDINGS REGARDING SURVEY PARTICIPANTS}

Research Question One asked how many days do teachers in preschool and childcare programs devote to reading aloud? Then how many days do teachers devote to reading nonfiction and fiction? (Table 4)

Over half of the 101 responses showed that they read every one of ten days $65(66 \%) ; 25(25 \%)$ reported reading five to nine days and $6(6 \%)$ selected less than 4 days. There was a distinct difference between the total number of days the early childhood teachers read nonfiction and fiction in ten days. The majority of teachers read nonfiction less than five days $(\mathrm{N}=65)$ and read fiction all ten days $(\mathrm{N}=59)$.

Table 4

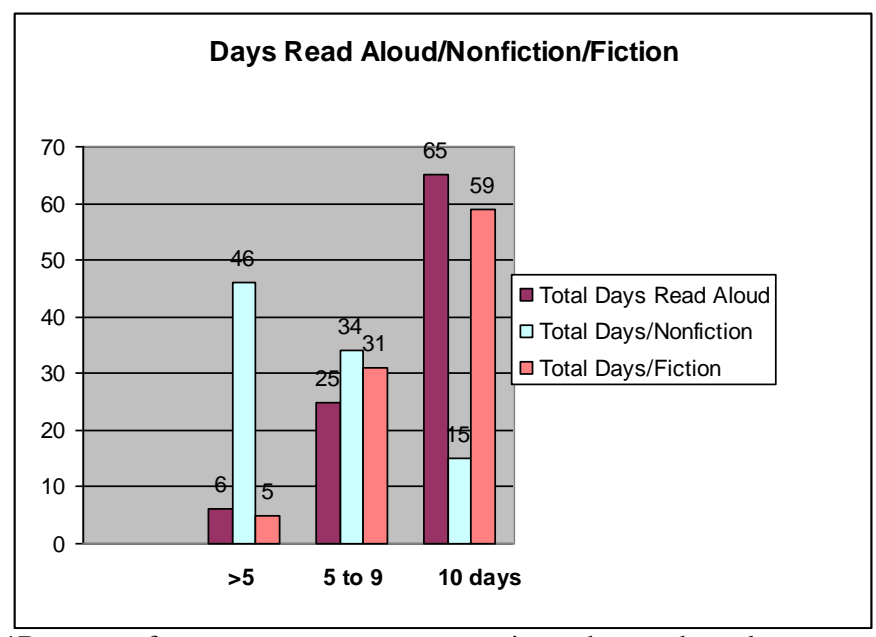

*Because of non-response to some questions, the numbers do not add up to 101 of the total participants.

Research Question Two asked how many minutes are given to reading aloud? Then how many minutes are used for reading nonfiction and fiction? (Table 5)

Teachers were asked how many minutes per day they read nonfiction and how many minutes per day they read fiction to the children in the past 10 days. The response of minutes showed that the majority, 64 respondents read 20 minutes per day. There were 25 that read 45 minutes and five who chose 45 minutes. Two respondents read less than 10 minutes per day. 
The teachers were asked to estimate how many minutes they read nonfiction and fiction to the children per day. The response of minutes showed that 14 respondents read nonfiction and only five read fiction less than 10 minutes per day. There were 61 that read nonfiction and 66 that read fiction 30 minutes. There were 18 that read nonfiction and 23 that read fiction between 45 minutes. Three respondents read nonfiction and two read fiction more than 60 minutes per day.

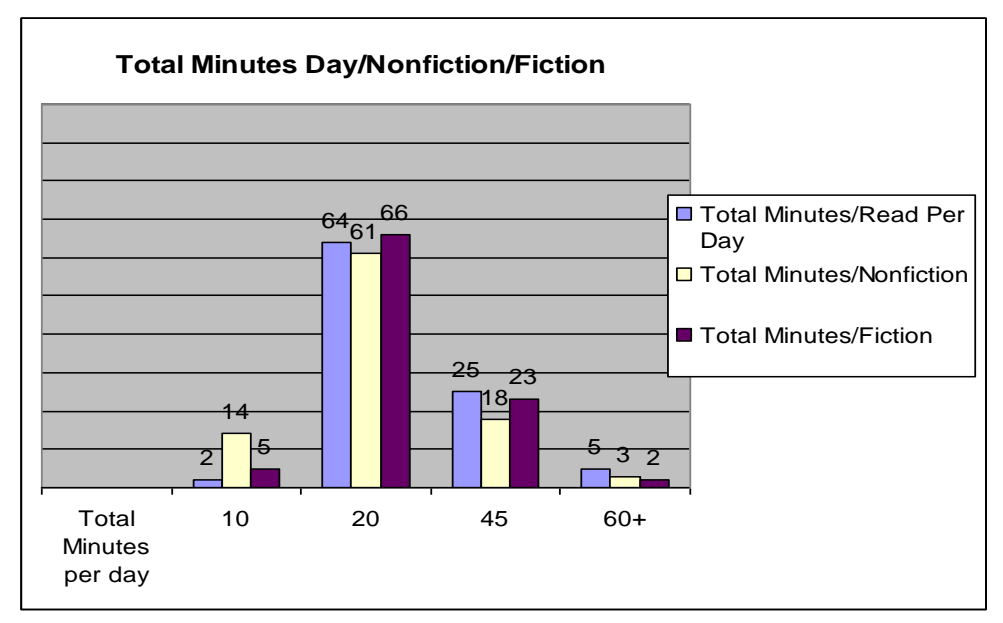

\section{FINDINGS}

Research Question One related to the amount of time and type of literature early childhood teachers read to their children. Respondents were asked how many days they read to children in the past 10 days. Most of the respondents indicated that they read between five to ten days (90\%). This is an indication that reading is a part of almost every day at these programs. Respondents were also asked whether differences existed in the days teachers spend reading nonfiction and fiction. There was a distinct difference between the total number of days they read nonfiction and fiction in ten days. Teachers $(\mathrm{N}=46)$ read nonfiction less than five days and reported reading fiction more than five days out of the past ten days $(\mathrm{N}=90)$.

Question Two asked to estimate how many minutes they read per day and how much time each day they read nonfiction and fiction. The response of minutes showed that most $(\mathrm{N}=60)$ read 20 minutes per day.

\section{CONCLUSIONS}

The following conclusions are based on the findings of this study:

1. Reading does take place almost every day in early childhood programs though the amount of time devoted each day to reading aloud may not be enough to support young children' needs.

2. In this study, nonfiction literature is not being read aloud as frequently as fiction literature in early childhood classrooms.

\section{SUMMARY}

The purpose of this study was to determine the amount of time teachers in the early years used interactive read-alouds using specific types of text. A survey asking early childhood teachers about their read aloud practices and use of nonfiction and fiction literature was distributed to provide insight into classroom reading behaviors. 
Findings of the study were limited to a specific group of teachers in a Midwest community. Generalizations to the larger population cannot be made from the findings.

This study did show a large difference in the amount of time that teachers read nonfiction compared to how much they read fiction to their young children. This supports the research in the field that shows the use of nonfiction literature has not been the norm in classrooms. Though there were few studies that focused on its use with young emergent readers, the research involved children that already could read in elementary school (Duke \& Kays, 1998) or with parents reading individually or one-on-one with their young child (Maduram, 2000).

There are several reasons why this researcher believes that the use of nonfiction is not being utilized in programs for young children. First, reading nonfiction aloud to small children can be a challenge. Reading fiction seems to capture children's interest because they enjoy the story while nonfiction needs some interesting "ploys" to first get and then keep the children's interest.

Reading an informational book about a topic, such as bears, would be interesting to some of the children, but not to all. Children are not always interested in topics that teachers plan as themes; therefore, they may not seem interested in the books on those topics. If children were allowed to have books that had topics they asked about, they would be much more involved in listening and questioning. The young child may be more willing to question and make comments during the book reading about the facts in a book that they chose.

Preschool children listen and understand when they can relate to the concepts both in play and in book reading. This supports the extensive research that children need to be actively involved to learn and understand new concepts and vocabulary. When a book text explains what the three characteristics of an insect are, a fingerplay using plastic insects would support the active learning. Concrete materials and examples capture and hold the interest of the young children more than simply reading facts from the book.

Teachers need to understand the developmental needs of young children to make nonfiction as interesting as a fiction story. The use of nonfiction literature should be considered in early childhood classrooms based on the interests of the children. Exposing children to this genre is important. There has been considerable emphasis on reading to children in the early years and the importance of making reading to children a major priority in the classroom. Though teachers know that reading to children is important, the amount of time that is spent on reading aloud is small in comparison to the total time spent in the classroom.

The findings in this report have implications for practice in the field. Because vocabulary development is a key ingredient in the learning-to-read process, children must be given more opportunities in the preschool environment to increase their vocabulary during the developmental years. The use of read alouds and nonfiction literature are beneficial tools that early childhood teachers can use for this purpose.

\section{RECOMMENDATIONS FOR PRACTICE}

1. To maximize the benefits of reading, early childhood classrooms should emphasize reading as a more important activity, and encourage teachers to spend more time reading aloud.

2. Early childhood teachers should include nonfiction and need to consider developmental needs of young children whether reading books that are fiction or nonfiction. Teaching strategies to include this genre need to be considered such as using concrete examples and integrating the themes into their play experiences.

3. There must be a continuing effort in the education of early childhood teachers, caregivers, and parents on the importance of reading early and often to young children to help develop vocabulary and emerging literacy skills.

4. Although the publishers of children's books are supplying better quality and quantity of nonfiction books, they are still not as captivating as a good narrative picture book when reading to a group of children. Publishers should work toward publishing higher quality nonfiction books with interesting pictures and text that would be appropriate for emergent and beginning readers. 
5. Early childhood teachers should use paired books that would include a nonfiction book about a subject and a fiction story including that same subject. This would support children who had an interest in finding more about a topic or subject.

6. Further research on the amount of time and read-aloud strategies teachers and parents should use to read to achieve the best outcomes should be conducted. And the use of specific genres to attain the goal of literacy.

\section{AUTHOR INFORMATION}

Gayle M. Bortnem, EdD. Assistant professor in Education at Northern State University, Aberdeen, SD. MS in Elementary Administration, NSU 1996 and EdD in Curriculum and Instruction, University of South Dakota, Vermillion, SD in 2005. Teaches undergraduate classes of Children's Literature and Early Childhood and graduate classes in Curriculum. Student advisor for National Association for the Education of Young Children (NAEYC). A faculty member for 10 years receiving the Outstanding Faculty Award in May, 2008.

\section{REFERENCES}

1. Adams, M. (1990). Learning to read: Thinking and learning about print. Cambridge, MA: MIT Press.

2. Anderson, R., Heibert, E., Scott, J., \& Wilkinson, I. (1985). Becoming a nation of readers: The report of the Commission on Reading. Washington, DC: National Institute of Education.

3. Bowman, B. (2002). Love to read-Essays in developing and enhancing early literacy skills of African American children. National Black Child Development Institute, Inc.: Washington, D.C.

4. Brabham, E., \& Lynch-Brown, C. (2002). Effects of Teacher's Reading-aloud styles on vocabulary acquisition and comprehension of students in the early elementary grades. Journal of Educational Psychology, 94(3), 465-473.

5. Burns, M., Griffin, P., \& Snow, C. (Eds.). (1999). Starting out right: A guide to promoting children's reading success. Washington, DC: National Academy Press.

6. Bus, A., van IJzendoorn, M., \& Pellegrini, A. (1995). Joint book reading makes for success in learning to read: A meta-analysis on intergenerational transmission of literacy. Review of Educational Research, 65, 121.

7. Carey, S. (1978). The child as a word learner. Linguistic Theory and Psychological Reality. Cambridge, MA: MIT Press.

8. Caswell, L., \& Duke, N. (1998). Non-narrative as a catalyst for literacy development. Language Arts, 75, 108-117.

9. Cazden, C. (1983). Adult assistance to language development: Scaffolds, models, and direct instruction. In C. Cazden (Ed.), Developing literacy: Young children's use of language. Newark, DE: International Reading Association.

10. Chomsky, C. (1972). Stages in language development and reading exposure. Harvard Educational Review, 42, 1-33.

11. Crosser, S. (2004). Enhancing the language development of young children. Retrieved from http://www.early childhood.com/Articles/index.cfm.

12. Dickinson, D., McCabe, A., Anastasopoulos, L., Peisner-Feinberg, E., Poe, S., \& Michele D. (2003). Journal of Educational Psychology, 95(3), 465-81.

13. Dickinson, D., \& Smith, M. (1994). Long-term effects of preschool teachers' book readings on low-income children's vocabulary and story understanding. Reading Research Quarterly, 29(2), 105-122.

14. Dickinson, D., DeTemple, J., Hirschler, J., \& Smith, M. (1992). Book Reading with Preschoolers: Coconstruction of text at home and at school, Early Childhood Research Quarterly, 7, 323-346.

15. Dickinson, D. \& Tabors, P. (2002). Fostering language and literacy in classrooms and homes. Young Children, 57(2), 10-18.

16. Duke, N. (2000). 3.6 minutes per day: The scarcity of informational texts in first grade. Reading Research Quarterly, 35, 202-224.

17. Duke, N. (2003). Reading to learn from the very beginning: Information books in early childhood. Young Children, 58(2), 14-20.

18. Duke, N., \& Kays, J. (1998). “Can I say ‘Once upon a time'?” Kindergarten children developing knowledge of information book language. Early Childhood Research Quarterly, 132, 295-318. 
19. Duke, N., \& Bennett-Armistead, S. (2004). Reading and Writing Informational Text in the Primary Grades: Research-based practices. Scholastic, Inc.

20. Durkin, D. (1972). Teaching young children to read. Boston: Allyn \& Bacon.

21. Elley, W.B. (1980). A comparison of content-interest and structuralist reading programs in nine primary schools, New Zealand Journal of Educational Studies, 15, 39-53.

22. Elley, W.B. (1989). Vocabulary acquisition from listening to stories. Reading Research Quarterly, 24, 17487.

23. Feitelson, D., \& Goldstein, Z. (1986). Patterns of book ownership and reading to young children in Israeli school-oriented and nonschool-oriented families. The Reading Teacher, 39, 924-930.

24. Foster, C., Hough, R., \& Matthews, M. (1991). Classroom language instruction modeled on the ways families talk. Dimensions, 19(2), 9-12.

25. Hart, B., \& Risley, T. (1995). Meaningful differences in the everyday experiences of young American children. Baltimore: Paul H. Brookes Publishing Co.

26. Huck, C. (1979). Children's literature in the elementary classroom (3rd ed.). New York, NY: Holt, Rinehart \& Winston.

27. International Reading Association, (1995). Learning to Read and Write: Developmentally Appropriate Practices for Young Children. Newark, DE: IRA.

28. International Reading Association \& National Association for the Education of Young Children, (1999). Joint position statement. Overview Online: naeyc.org/resources/position_statements/psread.htm.

29. Jacobs, J.S., Morrison, T. \& Swinyard, W. (2000). Reading aloud to students: A national probability study of classroom reading practices of elementary school teachers. Reading Psychology, 21(3), 171-194.

30. Jenkins, J. R., Stein, M. L., \& Wysocki, K. (1984). Learning vocabulary through reading. American Educational Research Journal, 21, 767-787.

31. Juel, C. (1991). Beginning reading. In R. Barr, M. i. Kamil, P.B. Mosenthal, \& P. D. Pearson (Eds), Handbook of Reading Research (Vol.2, pp.759-788). Mahwah, NJ: Lawrence Eribaum Associates.

32. Juel, C., Griffith, P.L. and Gough, P. B. (1986). Acquisition of literacy: A longitudinal study of children in the first and second grade. Journal of Educational Psychology, 78, 243-255.

33. Justice, L.M. (2002). Word exposure conditions and preschoolers' novel word learning during shared storybook reading. Reading Psychology, 23, 87-106.

34. Justice, L.M. \& Ezell, H.K. (2001). Written language awareness in preschool children from low-income households: A descriptive analysis. Communication Disorders Quarterly, 22, 123-134.

35. Justice, L. M., \& Kaderavek, J. N. (2004). Embedded-Explicit emergent literacy intervention I: background and description of approach. Language, Speech \& Hearing Services in Schools, 35, 201-221.

36. Kamil, M.L., \& Lane, D. (1997). A classroom study of the efficacy of using information text for first-grade reading instruction. Paper presented at the annual meeting of the American Educational Research Association, Chicago.

37. Klesius, J., \& Griffith, P. (1996). Interactive storybook reading for at-risk learners. The Reading Teacher, 49(7), 552-560.

38. Lee, V.E., \& Burkam, D.T. (2002). Inequality at the starting Gate. Washington, D.C.: Economic Policy Institute.

39. Lillebo, J. D. (2003). Survey of teachers in South Dakota.

40. Maduram, I. (2000). "Playing possum" A young child's responses to information books, Language Arts, 77, 391-97.

41. Moats, L. C. (2000). Speech to print. Baltimore: Paul H. Brookes.

42. Morrow, L. M., \& Smith, J. K. (1990). The effect of group size on interactive storybook reading. Reading Research Quarterly, 25(3), 213-231.

43. Moss, B. (1997). A qualitative assessment of first graders' retelling of expository text. Reading Research and Instruction, 37, 1-13.

44. Nagy, W. E., Anderson, R. C., \& Herman, P. A. (1987). Learning word meanings from context during normal reading. American Educational Research Journal, 24, 237-270.

45. Nagy, W.E., \& Herman, P. A. (1987). Breadth and depth of vocabulary knowledge: Implications for acquisition and instruction, In M.G. McKeown \&M. E. Curtis (Eds), The nature of vocabulary acquisition (pp. 19-35) Hillsdale,NJ: Erlbaum. 
46. National Reading Panel, (2000). Teaching children to read: An evidence-based assessment of the scientific research literature on reading and its implications for reading instruction. NIH Publication No. 00-4769. Washington, DC: National Institute of Child Health \& Human Development National Institutes of Health.

47. Neuman, S. B. (2003). The Case for High-Quality Prekindergarten. Phi Delta Kappan, 85(4), $286-291$.

48. Neuman, S. B., Copple, C., \& Bredekamp, S. (2000). Learning to read and write, Developmentally Appropriate Practices for Young Children. National Association for the Education of Young Children: Washington, DC.

49. Neuman, S. B., \& Dickinson, D. K. (2002). Handbook of early literacy research. The Guilford Press: New York.

50. Ninio, A. (1980). Picture-book reading in mother-infant dyads belonging to two subgroups in Israel. Child Development, 51, 587-590.

51. Pappas, C. C. (1993). Is narrative "primary"? Some insights from kindergartners' pretend readings of stories and information books. Journal of Reading Behavior, 24, 97-129.

52. Pappas, C.C. (1991). Fostering full access to literacy by including information books. Language Arts, 68, 449-462.

53. Pellegrini, A., Perlmutter, J., Galda, L., \& Brody, G. (1990). Joint reading between black head start children and their mothers. Child Development, 61(2), 443-453.

54. Penno, J., Wilkinson, I., \& Moore, D. (2002). Vocabulary acquisition from teacher explanation and repeated listening to stories: Do they overcome the Matthew Effect? Journal of Educational Psychology, 94 (1), 23-33.

55. Purcell-Gates, V., \& Duke, N.K. (2001). Explicit explanation/teaching of informational text genres: A model for research. Paper presented at the National Science Foundation Conference "Crossing Borders: Connecting Science and Literacy," 24-26 August, in Baltimore, Maryland.

56. Robbins, C., \& Ehri, L. (1994). Reading storybooks to kindergartners helps them learn new vocabulary words. Journal of Educational Psychology, 86(1), 54-64.

57. Sanacore, J. (1991). Expository and narrative text: Balancing young children's reading experiences. Childhood Education, 67, 211-214.

58. Scarborough, H., \& Dobrich, W. (1994). On the efficacy of reading to preschoolers. Developmental Review, 14, 245-302.

59. S'en 'echal, M. (1997). The differential effect of storybook reading on preschoolers' acquisition of expressive and receptive vocabulary. Journal of Child Language, 24, 123-138.

60. Schickedanz, J. A. (1999). Much more than the ABC's, the early stages of reading and writing. National Association for the Education of Young Children: Washington, D.C.

61. Smolkin, L.B., Donovan, C.A. (2001). The contexts of comprehension: Information book read-alouds and comprehension acquisition. Elementary School Journal, 102,97-122.

62. Smolkin, L.B., Donovan, C.A.(2003). Supporting Comprehension Acquision For Emerging and Struggling Readers: The Interactive Information Book Read Aloud. Exceptionality, 11, 25-38.

63. Snow, C., Barnes, W., Chandler, J., Goodman, I., \& Hemphill, L. (1991).Unfulfilled expectations: Home and school influences on literacy. Cambridge, MA: Harvard University Press.

64. Snow, C.E., Burns, S.M., \& Griffin, P. (1998). Preventing Reading Difficulties in Young Children by the National Research Council, Executive Summary. National Research Council. Starting out Right: A guide to promoting children's reading success. Washington, DC: National Academy Press.

65. Stanovich, K. E. (1986). Matthew Effects in reading: Some consequences of individual differences in the acquisition of literacy. Reading Research Quarterly, 21, 360-407.

66. Sulzby, E. (1985). Children's emergent reading of favorite storybooks: A developmental study. Reading Research Quarterly, 20, 458-481.

67. Sulzby, E., \& Teale., W. (1991). Emergent literacy. In Barr, R., Kamil, M.L., Mosenthal, R.B. \& Pearson, P.D. (Eds.), Handbook of Reading research (2), 727-757. New York: Longman.

68. Sulzby, E., \& Teale. W. (1987). Young children's story-book reading: A longitudinal study of parent-child interaction and children's independent functioning. Ann Arbor: The University of Michigan.

69. Teale, W. H. (1986). Home background and young children's literacy development. Emergent literacy: Writing and reading, 173-206. Norwood. NJ:Ablex.

70. U. S. Department of Education (2002). No Child Left Behind Act, Early Reading First. Washington, DC. 
71. Vukelich, C, Christie, J. \& Enz, B. (2002). Helping young children learn language and literacy. Boston, MS: Allyn and Bacon.

72. Vygotsky, L. S. (1978). Mind in society: The development of psychological processes. Cambridge, MA: Harvard University Press.

73. Wells, G. (1986). The meaning-makers: Children learning language and using language to learn. Portsmouth, NH: Heinemann.

74. Wells, G. (1987). Apprenticeship in literacy. Interchange, 18, 109-123.

75. Whitehurst, G. J., Epstein, A. L., Angell, A. C., Crone, D. A., \& Fischel, J. E.(1994). Outcomes of an emergent literacy intervention in Head Start. Journal of Educational Psychology, 86, 542-555.

76. Whitehurst, G. J., \& Fischel, J. E. (2000). A developmental model of reading and language impairments arising in conditions of economic poverty. In D. Bishop \& L. Leonard (Eds.), Speech and language impairment: From theory to practice (pp. 53-71). East Sussex: Psychology Press.

77. Wisendanger, K. (2001). Strategies for literacy education. Upper Saddle River, NJ: Merrill Prentice Hall.

78. Yaden, D., Smolkin, L., \& Conlon, A. (1989). Preschoolers' questions about pictures,print conventions, and story text during reading aloud at home. Reading Research Quarterly, 24, 188-214.

79. Zill, N., \& Collins, M. (2000). Approaching Kindergarten: A look at preschoolers in the United States. Washington, D.C.: National Center for Education Statistics. 


\section{NOTES}

